\title{
Pengaruh Densitas Terhadap Kecepatan Pemisahan Biodiesel/Gliserin
}

\author{
Drajat Indah Mawarni ${ }^{1 a}$ \\ ${ }^{a}$ Sekolah Tinggi Teknologi Ronggolawe Cepu
}

Received : 2020-10-07

Reviewed : 2020 -

Online Published : 31-12-2020

\begin{abstract}
This study aims to determine the level of creaming velocity between two fluids with the same phase but different densities. This study was carried out experimentally by observing and measuring the settling time on a glass tube with various diameters. Measurement of separation time was carried out five times for each tube diameter. The separation time obtained is used as the basis for calculating droplet diameter, droplet concentration, creaming velocity and Vstokes. The calculation results obtained were plotted to compare the value of the droplet consentration (terhadap) to the creaming velocity of the biodiesel / glycerin mixture and to find the $\Phi c$ value (volume fraction of the biodiesel phase densely dispersed in glycerin / droplet concentration) and $k$ (separation constant).

From this research it can be concluded that the higher the drop concentration value ( $\Phi)$, the separation speed (V cream) will decrease and from the Hunter equation that $V=$ Vstokes $(1-\Phi / \Phi c) k . \Phi_{c}$, the $k$ and $\Phi_{c}$ values are obtained respectively. - respectively (5.1; 0.6; 1.2$)$ and (0.461; 0.9; 0.69) in experiments I, II, III with a tube diameter $(1.3 ; 2.8 ; 3.9) \mathrm{cm}$.
\end{abstract}

Keywords: settling time, droplet, droplet concentration, velocity creaming,

\section{Abstrak}

Kajian ini bertujuan untuk mengetahui tingkat kecepatan pemisahan (creaming velocity) antara dua fluida yang berfasa sama namun memiliki perbedaan densitas. Kajian ini dilakukan secara eksperimental dengan mengamati dan mengukur waktu pisah (settling time) pada tabung kaca dengan variasi diameter.Pengukuran waktu pisah dilakukan lima kali untuk setiap diameter tabung. Waktu pisah yang di peroleh digunakan sebagai dasar untuk menghitung diameter tetesan/droplet, konsentrasi tetesan, kecepatan pemisahan/creaming velocity dan Vstokes. Hasil perhitungan yang di peroleh diploting untuk membandingkan nilai konsentrasi tetesan (droplet consentration/ $\Phi$ ) terhadap kecepatan pemisahan (creaming velocity) pada campuran biodiesel/gliserin dan untuk mencari nilai $\Phi_{c}$ (fraksi volume fase biodiesel yang terdispersi rapat dalam gliserin/konsentrasi tetesan) dan k (konstanta pemisahan).

Dari penelitian ini dapat disimpulkan bahwa semakin tinggi nilai konsentrasi tetesan $(\Phi)$ maka kecepatan pemisahannya (V cream) akan semakin berkurang dan dari persamaan Hunter bahwa $\mathrm{V}=\mathrm{V}$ stokes $\left(1-\frac{\Phi}{\Phi c}\right)^{\mathrm{k} . \Phi \mathrm{c}}$, maka didapatkan nilai $\mathrm{k}$ dan $\Phi_{\mathrm{c}}$ masing - masing adalah $(5,1$; $0,6 ; 1,2)$ dan $(0,461 ; 0,9 ; 0,69)$ pada percobaan I, II, III dengan diameter tabung $(1,3 ; 2,8 ; 3,9) \mathrm{cm}$.

Kata kunci: settling time, droplet, droplet concentration, velocity creaming

\section{Pendahuluan}

Pemisahan yang terjadi antara dua fluida secara gravitasi merupakan salah satu bentuk ketidakstabilan dari sebuah emulsi.Fenomena yang dihasilkan adalah berupa peristiwa creaming(pemisahan) dan peristiwa sedimentation (pengendapan), tergantung nilai densitas dari fasa terdispersi (fasa dengan nilai densitas rendah) dan fasa kontinyu (fasa dengan nilai densitas tinggi). Creaming adalah peristiwa bergeraknya partikel tetesan/droplet ke atas sebagai akibat dari nilai densitasnya yang lebih rendah dari nilai densitas fluida lingkungannya. Dalam campuran biodiesel dan gliserin, partikel biodiesel bergerak keatas ketika proses pemisahan terjadi sebagai akibat dari nilai densitas biodiesel lebih rendah dari nilai densitas gliserin. Sehingga dalam pernyataannya dapat dinyatakan sebagai biodiesel in gliserin emulsion atau fasa biodiesel terdispersi di dalam fasa gliserin atau biodiesel/gliserin, sedangkan sedimentasi adalah bergeraknya partikel tetesan atau droplet ke bawah sebagai akibat dari nilai densitannya yang lebih tinggi dari nilai densitas fluida sekelilingnya. Sehingga dalam pernyataannya dapat dinyatakan sebagai gliserin in biodiesel emulsion atau fasa gliserin terdispersi di dalam fasa biodiesel atau gliserin / biodiesel. Dalam campuran biodiesel dan gliserin, proses terjadinya pemisahan atau creaming velocity antara biodiesel dan gliserin sangat bermanfaat untuk mendapatkan produk biodiesel murni dengan metode yang sederhana yaitu pemisah gravitasi berdasar perbedaan nilai densitas. Dengan asumsi bahwa fluida bersifat Newtonian maka berlaku hukum Stoke's yaitu :

Vstokes $=-\frac{2 \cdot g \cdot r 2 \cdot(\rho 2-\rho 1)}{9 \cdot \eta}$

dengan $r$ : jari-jari partikel tetesan $(m), \rho$ : densitas fluida $\left(\mathrm{kg} / \mathrm{m}^{3}\right)$,g: percepatan gravitasi $\left(\mathrm{m} / \mathrm{s}^{2}\right)$, dan $\eta$ : viskositas 
fluida. Tanda (+) dan (-) pada Vstokes menunjukkan arah aliran droplet ke atas dan ke bawah.

Teori ini (v-stokes) telah dikembangkan dengan mempertimbangkan berbagai faktor seperti ketidakstabilan tetesan partikel, konsentrasi tetesan partikel, lapisan antar permukaan fluida dan dengan mempertimbangkan ketika fasa bersifat non-Newtonian, maka secara empiris diturunkan sebuah persaman yang mengacu pada hukum Stoke's yang dirumuskan oleh Hunter,1989, yaitu :

$\mathrm{V}=\mathrm{V}$ stokes $\left(1-\frac{\Phi}{\Phi c}\right)^{\mathrm{k} . \Phi}$

dengan $\mathrm{V}$ adalah $\mathrm{V}$ creaming atau kecepatan pemisahan antara dua fluida, v-stokes adalah kecepatan sebuah partikel ketika bergerak terpisah dari fluida campurannya,Фc dan k adalah parameter yang tergantung dari sifat tetesan partikel seperti sifat ukuran partikel, polidispersitas atau keberagaman bentuk tetesan partiel dan sifat interaksi koloid antar tetesan partikel. Untuk suspensi koloid monodispherse nonflocculated nilai $\mathrm{k}$ dan $\Phi \mathrm{c}$ adalah 5,4 dan kisaran antara 0,5-0,6. Dari persamaan Hunter ini dapat diketahui bahwa semakin tinggi nilai konsentrasi tetesan maka kecepatan pemisahan/creaming velocity semakin berkurang.

\section{Tinjauan Pustaka}

\subsection{Kajian Pustaka}

Dalam proses produksi biodiesel, minyak dan lemak padat dicampur dengan alkohol untuk menghasilkan biodiesel dan gliserin.

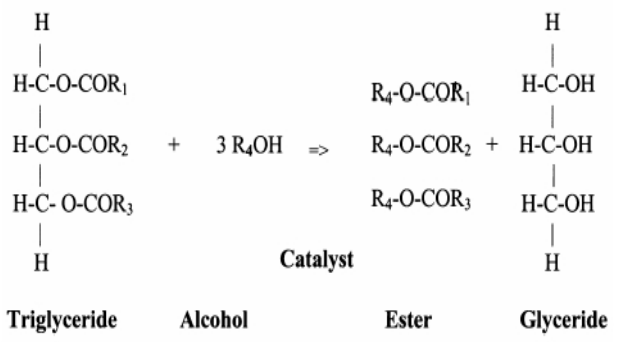

Figure 1: Transesterification reaction (Peterson et al 2002)

Kedua cairan yang dihasilkan dari reaksi diatas yaitu biodiesel dan gliserin harus dipisahkan untuk mendapatkan biodiesel murni. Ada dua metode dalam proses pembuatan biodiesel yaitu proses Batch dan proses Kontinyu biodiesel dasar transesterifikasi. Dalam proses batch,reaksi terjadi dalam tangki yang diam. Namun, dalam proses kontinyu, bahan baku, alkohol, dan katalis dialirkan terus-menerus selama proses. Dalam proses pembuatan biodiesel dengan sistem kontinyu, pemisahan dengan metode sentrifugal banyak digunakan, namun metode pemisahan sentrifugal lebih mahal dan lebih rumit dalam mengoperasikan, terutama untuk produksi dengan skala kecil. Namun jika pembuatan biodiesel dengan menggunakan proses batch, metode pemisahan sentrifugal dapat diganti dengan metode pemisah gravitasi.

Campuran biodiesel / gliserin adalah berupa tetesan /droplet dari gliserin yang tersebar dalam biodiesel.

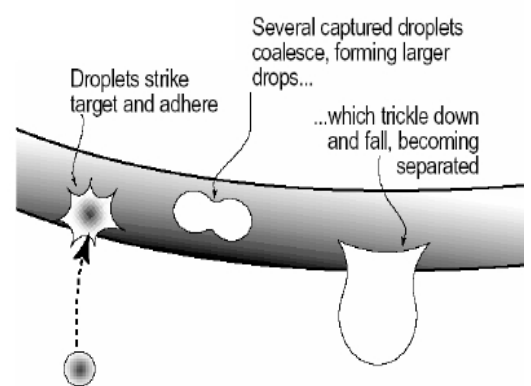

Figure 2 : Diagram of coalescence (ACS 2003)

Jika campuran ini ditempatkan ke dalam tangki dan tidak ada gerakan fluida, maka gaya gravitasi dapat menyebabkan tetesan gliserin terpisah dari biodiesel dan membentuk lapisan gliserin di bawah lapisan biodiesel. Tangki penampung dengan proses ini disebut dengan sistem batch. Pada tahun 1997, Parichay K. Das mengusulkan pemodelan seperti itu dalam bukunya yang berjudul "Prediksi Kecepatan Pengendapan dari Tetesan yang terdapat dalam Dispersi Liquid-Liquid dengan sistem Batch".

Pada penelitian ini, waktu pemisahan dari model dibandingkan dengan waktu pemisahan dari eksperimen. Diharapkan bahwa model ini bisa akurat untuk memprediksi waktu pemisahan dari dispersi cair-cair, namun, setelah dibandingan, ternyata bahwa model tidak akurat bila dibandingkan dengn hasil eksperimen. Penelitian berikutnya dilakukan oleh para peneliti dari Universitas Idaho dengan menggunakan sistem pemisahan kontinyu yang didasarkan pada model Das namun model itu juga masih belum sempurna.Peneliti berikutnya adalah John Dail Garner(2005), yang melakukan penelitian dengan menggunakan dasar atas penelitian yang dilakukan oleh Das dan yang telah dikembangkan oleh NadivSemiat.Eksperimen yang dilakukan menggunakan 4 buah tabung yang memiliki perbedaan ukuran diameter maupun ketinggian,yaitu diameter $(4,8$ dan 8,0$) \mathrm{cm}$ dan ketinggian $(13,1$ dan 25,2$) \mathrm{cm}$ dengan pengambilan data untuk setiap sampel percobaan sebanyak 20 data.

Namun demikian hasil yang diperoleh masih belum optimal antara model numerik yang digunakan dengan eksperimen yang dilakukan yaitu dengan faktor kesalahan sebesar $26,3 \%$.

Mengacu pada kondisi yang demikian, penulis mencoba untuk mengulangi eksperimen yang dilakukan Jhon Dail Garner dengan menggunakan variasi diameter dan ketinggian tabung yang lebih variatif dan diharapkan akan mendapatkan hasil yang lebih baik. 


\subsection{Landasan Teori}

\subsubsection{Kecepatan pemisahan}

Dengan asumsi bahwa fluida bersifat Newtonian maka berlaku hukum Stoke's yaitu :

Vstokes $=-\frac{2 \cdot g \cdot r 2 \cdot(\rho 2-\rho 1)}{9 \cdot \eta}$

dengan $r$ : jari-jari partikel tetesan $(m), \rho$ : densitas fluida $\left(\mathrm{kg} / \mathrm{m}^{3}\right), \mathrm{g}$ : percepatan gravitasi $\left(\mathrm{m} / \mathrm{s}^{2}\right)$, dan $\eta$ : viskositas fluida. Tanda (+) dan (-) pada Vstokes menunjukkan arah aliran droplet ke atas dan ke bawah.

Teori ini (v-stokes) telah dikembangkan dengan mempertimbangkan berbagai faktor seperti ketidakstabilan tetesan partikel, konsentrasi tetesan partikel, lapisan antar permukaan fluida dan dengan mempertimbangkan ketika fasa bersifat non-Newtonian, maka secara empiris diturunkan sebuah persaman yang mengacu pada hukum Stoke's yang dirumuskan oleh Hunter(1989) yaitu :

$$
\mathrm{V}=\operatorname{Vstokes}\left(1-\frac{\Phi}{\Phi c}\right)^{\mathrm{k} \cdot \Phi}
$$

dengan $\mathrm{V}$ adalah $\mathrm{V}$ creaming atau kecepatan pemisahan antara dua fluida, v-stokes adalah kecepatan sebuah partikel ketika bergerak terpisah dari fluida campurannya, $\Phi \mathrm{c}$ dan $\mathrm{k}$ adalah parameter yang tergantung dari sifat tetesan partikel seperti sifat ukuran partikel, polidispersitas atau keberagaman bentuk tetesan partikel dan sifat interaksi koloid antar tetesan partikel. Untuk suspensi koloid monodispherse nonflocculated nilai $\mathrm{k}$ dan $\Phi \mathrm{c}$ adalah 5,4 dan kisaran antara 0,5-0,6. Dari persamaan Hunter ini dapat disimpulkan bahwa semakin tinggi nilai konsentrasi tetesan maka kecepatan pemisahan/creaming velocity semakin berkurang.

\section{Metodologi Penelitian}

3.1. Urutan Penelitian

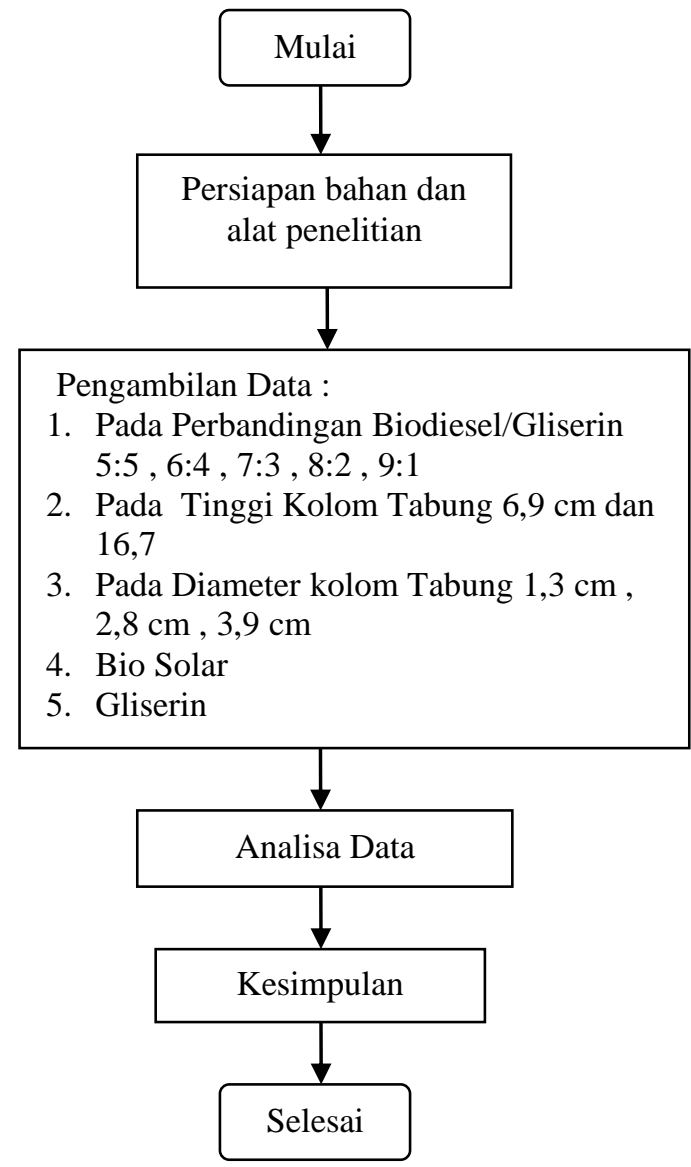

Gambar 5. Flow Chart Penelitian

\subsection{Waktu dan Tempat Penelitian}

Penelitian dilakukan di Workshop STTR Cepu pada tanggal 8 Desember 2010.

\subsection{Bahan dan Peralatan Penelitian}

Bahan yang digunakan dalam penelitian ini adalah biosolar dan gliserin, sedangkan peralatan yang digunakan dalam penelitian adalah:

1. Magnetic Stirrer

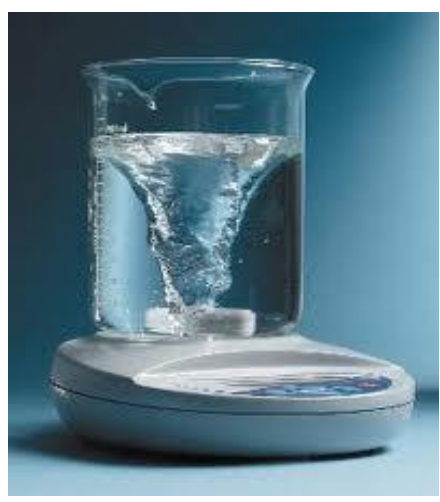

Magnetic Stirrer

\subsection{Urutan Kegiatan Penelitian}

1) Menentukan komposisi perbandingan biodiesel dan gliserin yang akan dihomogenkan, yaitu (5:5, 6:4, 7:3, $8: 2$, 9:1) berdasarkan ketinggian kolom tabung 
kemudian dihomogenkan dengan menggunakan magnetic stirrer.

2) Proses homogenisasi campuran antara biodiesel dan gliserin dilakukan selama 60 menit.

3) Tinggi kolom tabung yang digunakan adalah $6,9 \mathrm{~cm}$ dan $16,7 \mathrm{~cm}$.

4) Diameter kolom tabung yang digunakan adalah $1,3 \mathrm{~cm}$; $2,8 \mathrm{~cm}$ dan $3,9 \mathrm{~cm}$.

5) Menuangkan campuran yang sudah homogen ke dalam tabung

6) Mengamati pemisahan yang terjadi antara biodiesel dan gliserin sampai terbentuk dua lapisan biodiesel dan gliserin dalam kondisi tetap/maksimal.

7) Mencatat waktu pemisahan yang terjadi.

\section{Hasil dan Pembahasan}

\subsection{Data Hasil Penelitian}

Data hasil penelitan ini ditampilkan dalam tabel 5.1 sampai dengan tabel 5.10 (terlampir)

\subsection{Pembahasan}

\subsubsection{Waktu pemisahan optimal pada tabung dengan diameter $1,3 \mathrm{~cm}$ dan tinggi tabung $6,9 \mathrm{~cm}$}

Tabel 4.1. Data ketinggian biodiesel dan gliserin setelah pemisahan optimal pada tabung diameter $1,3 \mathrm{~cm}$ dan tinggi tabung $6,9 \mathrm{~cm}$

\begin{tabular}{ccccc}
\hline $\mathbf{t}_{\text {set }}(\mathbf{s})$ & $\mathbf{L}$-bio $(\mathbf{m})$ & $\mathbf{L}$-gli $(\mathbf{m})$ & $\mathbf{L}(\mathbf{m})$ & $\mathbf{V}_{\text {cream }}(\mathbf{m} / \mathbf{s}$ \\
& & & & \\
\hline $\mathbf{6 9 , 4}$ & $6,03.10^{-2}$ & $0,67.10^{-2}$ & $3,35.10^{-2}$ & 1,1900 \\
\hline $\mathbf{2 3}$ & $5,36.10^{-2}$ & $1,34.10^{-2}$ & $3,35.10^{-2}$ & 0,5230 \\
\hline $\mathbf{1 0 , 6}$ & $4,69.10^{-2}$ & $2,01.10^{-2}$ & $3,35.10^{-2}$ & 0,3160 \\
\hline $\mathbf{6 , 4}$ & $3,94.10^{-2}$ & $2,76.10^{-2}$ & $3,35.10^{-2}$ & 0,1540 \\
\hline $\mathbf{2 , 8}$ & $3,35.10^{-2}$ & $3,35.10^{-2}$ & $3,35.10^{-2}$ & 0,0435 \\
\hline
\end{tabular}

a. $t_{\text {set }}$ adalah waktu dalam detik yang diperlukan oleh biodiesel dan gliserin untuk terpisah secara sempurna / optimal. Pada baris pertama adalah data untuk campuran biodiesel : gliserin dengan perbandingan $9: 1$ dalam kolom setinggi $6,9 \mathrm{~cm}$ dengan diameter kolom $1,3 \mathrm{~cm}$ dan seterusnya pada baris kedua dengan perbandingan 8 : 2, baris ketiga $7: 3$, baris keempat $6: 4$ dan baris kelima $5: 5$

b. L-bio adalah ketinggian biodiesel dalam kolom dan diukur setelah campuran biodiesel-gliserin terpisah secara sempurna.

c. L-gli adalah ketinggian gliserin dalam kolom dan diukur setelah campuran biodiesel -gliserin terpisah secara sempurna d. L adalah tinggi rata-rata tetesan/droplet dalam kolom, dapat dicari dengan rumus:

$$
\mathrm{L}=\frac{1}{2} \mathrm{~L}_{\mathrm{bio}}+\frac{1}{2} \mathrm{~L}_{\mathrm{gli}}
$$

e. V creaming adalah kecepatan tetesan/droplet melakukan separasi atau terpisah sempurna, dapat dicari dengan menggunakan rumus:

$\mathrm{V}_{\text {cream }}=\frac{L}{t_{\text {set }}}$

dimana : $\mathrm{L}=$ tinggi rata-rata droplet

$$
\mathrm{t}_{\text {set }}=\text { waktu separasi }
$$

Dari data pada tabel 1, kemudian diploting antara $t_{\text {set }}$ terhadap $\mathrm{V}_{\text {cream}}$, di dapatkan hasil sebagai berikut :

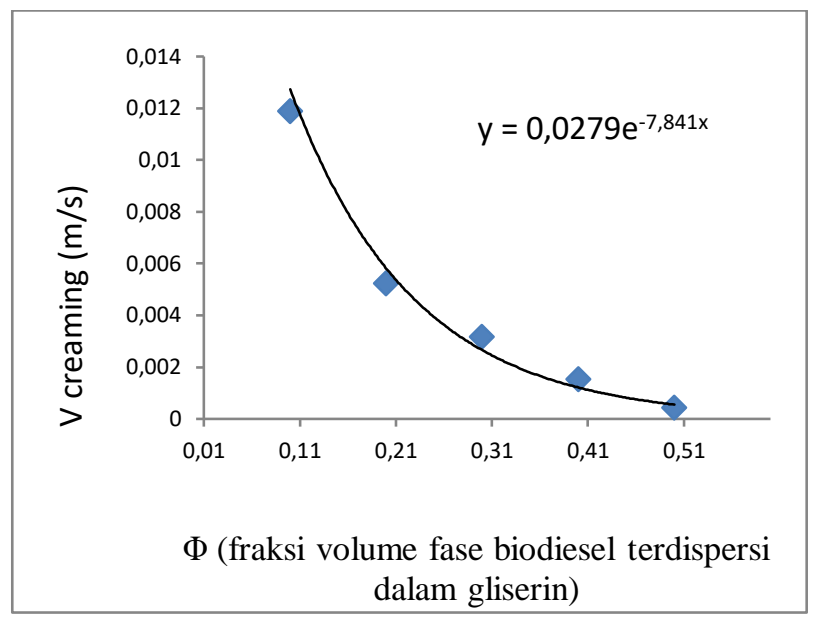

Grafik 1.Grafik t set terhadap V cream pada tabung dengan tinggi $6,9 \mathrm{~cm}$ dan diameter $1,3 \mathrm{~cm}$

Sumbu x pada grafik di atas menyatakan waktu separasi optimal dari campuran biodiesel-gliserin dengan perbandingan $9: 1,8: 2,7: 3,6: 4,5: 5$ atau secara empiris sumbu x menyatakan jumlah fraksi volume fase biodiesel yang terdispersi dalam gliserin $(\Phi)$

a. Sumbu y pada grafik di atas menyatakan $\mathrm{V}$ cream yaitu kecepatan dari tetesan/droplet untuk melakukan separasi secara optimal

c. Dari

ketika t set / $\Phi \approx 0$, maka

$\mathrm{V}$ cream $=\mathrm{V}$ stokes $(1-0)$

$\mathrm{V}$ cream $=\mathrm{V}$ stokes 
V stokes $=0,027$ dengan nilai

$\mathrm{V}$ stokes $=\frac{d^{2} \cdot g \cdot(\rho g l i-\rho b i o)}{18 \cdot \mu b i o}$ maka

$\mathrm{d} \quad=\sqrt{\frac{V \text { stokes.18. } \mu \text { bio }}{g \cdot(\text { ogli- } \rho \text { bio })}}$

sehingga nilai diameter tetesan/ droplet dapat diketahui yaitu nilai diameter tetesan (d) pada tabung dengan diameter 1,3 $\mathrm{cm}$ dan tinggi tabung $6,9 \mathrm{~cm}$ adalah : $8,64 \times 10^{-4} \mathrm{~m}$.

d. Ketika $\mathrm{V}$ cream $\approx 0$

$$
\begin{gathered}
\left(1-\frac{\Phi}{\Phi c}\right)^{k \cdot \Phi c}=0 \\
\Phi=\Phi c
\end{gathered}
$$

Tabel 4.2 Data $\Phi$ dan $\Phi_{\mathrm{c}}$ dari grafik 1

\begin{tabular}{cccc}
\hline L-bio $_{\text {-m) }}$ & L-gli $_{(\mathbf{m})}$ & $\boldsymbol{\Phi}$ & $\boldsymbol{\Phi}_{\mathbf{c}}$ \\
\hline $\mathbf{6 , 0 2 . 1 0 ^ { - 2 }}$ & $0,68 \cdot 10^{-2}$ & 0,1 & 0,461 \\
$\mathbf{5 , 3 6 . 1 0}$ & $1,34.10^{-2}$ & 0,2 & 0,461 \\
$\mathbf{4 , 6 9 . 1 0}^{-2}$ & $2,01.10^{-2}$ & 0,3 & 0,461 \\
$\mathbf{3 , 9 4 . 1 0}^{-2}$ & $2,76 \cdot 10^{-2}$ & 0,4 & 0,461 \\
$\mathbf{3 , 3 5 . 1 0}^{-2}$ & $3,35 \cdot 10^{-2}$ & 0,5 & 0,461
\end{tabular}

a. L-bio menyatakan ketinggian biodiesel di dalam kolom setelah terjadi separasi secara optimal

b. L-gli menyatakan ketinggian gliserin di dalam kolom setelah terjadi separasi secara optimal

c. $\Phi$ menyatakan fraksi volume fase biodiesel yang terdispersi dalam gliserin, dapat dihitung dengan menggunakan rumus :

$$
\Phi=\frac{\text { vi (volume total biodiesel })}{V \text { total }(\text { vol bio }+ \text { vol gli })}
$$

d. $\Phi_{\mathrm{c}}$ menyatakan konsentrasi droplet dalam keadaan rapat, tidak ada ruang gerak satu dengan yang lain (closely packed).

Tabel 4.3. Data harga $\mathrm{k}$ pada tabung diameter $1,3 \mathrm{~cm}$ dan tinggi tabung $6,9 \mathrm{~cm}$

\begin{tabular}{ccc}
\hline $\boldsymbol{\Phi}$ & $\mathbf{\Phi c}$ & $\mathbf{k}$ \\
\hline $\mathbf{0 , 1}$ & 0,461 & 1,70 \\
\hline $\mathbf{0 , 2}$ & 0,461 & 3,40 \\
\hline $\mathbf{0 , 3}$ & 0,461 & 5,10
\end{tabular}

\begin{tabular}{ccc}
\hline $\mathbf{0 , 4}$ & 0,461 & 6,80 \\
\hline $\mathbf{0 , 5}$ & 0,461 & 8,50
\end{tabular}

a. Dari grafik 1 di dapat persamaan yaitu :

$y=0,027 \cdot e^{-7,84 x}$

dari rumus diatas di empiriskan terhadap persamaan: $\mathrm{V}=$ Vstokes $\left(1-\frac{\Phi}{\Phi c}\right)^{\mathrm{k} . \Phi}$

didapat kesetaraan rumus sebagai berikut :

$$
\begin{aligned}
\mathrm{e}^{-7,84 \mathrm{x}} & =\left(1-\frac{\Phi}{\Phi c}\right)^{\mathrm{k} . \Phi} \\
\mathrm{k} . \Phi \mathrm{c} ; \mathrm{x} & \approx \Phi \\
\mathrm{k} & =\frac{-7,84 . \Phi}{\Phi c}
\end{aligned}
$$$$
-7,84 \mathrm{x}=
$$

b. $\Phi$ menyatakan fraksi volume fase biodiesel yang terdispersi dalam gliserin dalam bentuk satuan.

c. Фc menyatakan fraksi volume fase biodiesel yang terdispersi dalam gliserin dalam satu kesatuan yang rapat yang nilainya sangat dipengaruhi oleh ukurannya, tingkat keberagamannya dan interaksi koloidnya.

d. $\mathrm{k}$ menyatakan suatu konstanta yang nilainya sangat dipengaruhi oleh ukurannya, tingkat keberagamannya dan interaksi koloidnya.

Dalam percobaan dengan diameter kolom tabung $1,3 \mathrm{~cm}$ dan ketinggian kolom $6,9 \mathrm{~cm}$ didapat harga konstanta $\mathrm{k}: 5,1$ dan harga $\Phi_{\mathrm{c}}: 0,461$

\subsubsection{Waktu pemisahan optimal pada tabung dengan diameter $2,8 \mathrm{~cm}$ dan tinggi tabung $16,7 \mathrm{~cm}$}

Tabel 4.4. Data ketinggian biodiesel dan gliserin setelah pemisahan optimal pada tabung diameter $1,3 \mathrm{~cm}$ dan tinggi tabung $6,9 \mathrm{~cm}$

\begin{tabular}{cllll}
\hline set(S) & $\mathbf{L}_{\text {-bio }}(\mathbf{m})$ & $\mathbf{L}_{\text {-gli }}(\mathbf{m})$ & $\mathbf{L}(\mathbf{m})$ & $\mathbf{V}_{\text {cream }}(\mathbf{m} / \mathbf{s})$ \\
\hline $\mathbf{9 , 8}$ & $\begin{array}{l}15,03.10^{-} \\
2\end{array}$ & $1,67.10^{-2}$ & $8,35.10^{-2}$ & 0,00852 \\
& & & & \\
$\mathbf{1 2}$ & $\begin{array}{l}13,36.10^{-} \\
2\end{array}$ & $3,34.10^{-2}$ & $8,35.10^{-2}$ & 0,00696 \\
& & & & \\
$\mathbf{1 2 , 2}$ & $11,69.10^{-}$ & $5,01.10^{-2}$ & $8,35.10^{-2}$ & 0,00684 \\
& 2 & & & \\
$\mathbf{1 6 , 8}$ & $10,02.10^{-}$ & $6,68.10^{-2}$ & $8,35.10^{-2}$ & 0,00497 \\
& 2 & & & \\
$\mathbf{1 9 , 7}$ & $8,35.10^{-2}$ & $8,35.10^{-2}$ & $8,35.10^{-2}$ & 0,00423
\end{tabular}


a. t set adalah waktu dalam detik yang diperlukan oleh biodiesel dan gliserin untuk terpisah secara sempurna / optimal. Pada baris pertama adalah data untuk campuran biodiesel : gliserin dengan perbandingan $9: 1$ dalam kolom setinggi $16,7 \mathrm{~cm}$ dengan diameter kolom $2,8 \mathrm{~cm}$ dan seterusnya pada baris kedua dengan perbandingan 8 : 2, baris ketiga $7: 3$, baris keempat $6: 4$ dan baris kelima $5: 5$.

b. L-bio adalah ketinggian biodiesel dalam kolom dan diukur setelah campuran biodiesel-gliserin terpisah secara sempurna.

c. $\mathrm{L}_{\text {-gli }}$ adalah ketinggian gliserin dalam kolom dan diukur setelah campuran biodiesel -gliserin terpisah secara sempurna

d. L adalah tinggi rata-rata tetesan/droplet dalam kolom, dapat dicari dengan rumus:

$\mathrm{L}=\frac{1}{2} \mathrm{~L}_{\mathrm{bio}}+\frac{1}{2} \mathrm{~L}_{\mathrm{gli}}$

e. V creaming adalah kecepatan tetesan/droplet melakukan separasi atau terpisah sempurna, dapat dicari dengan menggunakan rumus:

$\mathrm{V}$ cream $=\frac{L}{t s e t}$

dimana :

$\mathrm{L}=$ tinggi rata-rata droplet

$\mathrm{t}_{\text {set }}=$ waktu separasi

Dari data pada tabel 4, kemudian diploting antara $\mathrm{t}$ set terhadap V cream, di dapatkan hasil sebagai berikut :

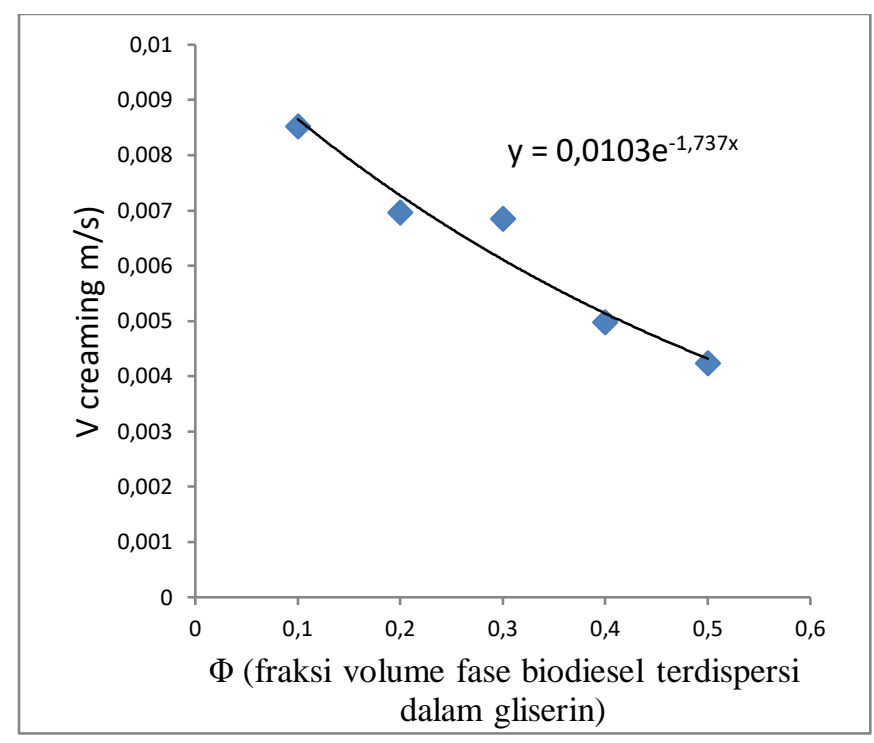

Grafik 2. Grafik t set terhadap V cream pada tabung dengan tinggi $16,7 \mathrm{~cm}$ dan diameter $2,8 \mathrm{~cm}$ a. Sumbu x pada grafik di atas menyatakan waktu separasi optimal dari campuran biodiesel-gliserin dengan perbandingan 9:1, 8:2, 7:3, 6:4, 5:5 atau secara empiris sumbu $\mathrm{x}$ menyatakan jumlah fraksi volume fase biodiesel yang terdispersi dalam gliserin $(\Phi)$

b. Sumbu y pada grafik di atas menyatakan $\mathrm{V}$ cream yaitu kecepatan dari tetesan/droplet untuk melakukan separasi secara optimal.

c. Dari rumus $\mathrm{V}=\operatorname{Vstokes}\left(1-\frac{\Phi}{\Phi c}\right)^{\mathrm{k} . \Phi}$ (15)

ketika $\mathrm{t}_{\text {set }} / \Phi \approx 0$, maka

$\mathrm{V}$ cream $=\mathrm{V}$ stokes $(1-0)$

$\mathrm{V}$ cream $=\mathrm{V}$ stokes

$\mathrm{V}$ stokes $=0,010$ dengan nilai

$\mathrm{V}$ stokes $=\frac{d^{2} \cdot g \cdot(\rho g l i-\rho b i o)}{18 \cdot \mu b i o}$

maka

$$
\mathrm{d} \quad=\sqrt{ } \frac{V \text { stokes.18. } \mu \text { bio }}{g \cdot(\text { ggli- } \rho \text { bio })}
$$

sehingga nilai diameter tetesan/ droplet dapat diketahui yaitu nilai diameter tetesan (d) pada tabung dengan diameter 2,8 $\mathrm{cm}$ dan tinggi tabung $16,7 \mathrm{~cm}$ adalah : $5,3 \times 10^{-4} \mathrm{~m}$.

d. Ketika $\mathrm{V}$ cream $\approx 0$

$$
\begin{gathered}
\left(1-\frac{\Phi}{\Phi c}\right) \text { k. } . \bar{c}=0 \\
\Phi=\Phi c
\end{gathered}
$$

Tabel 4.5 Data $\Phi$ dan $\Phi_{\mathrm{c}}$ dari grafik 2

\begin{tabular}{cccc}
\hline L-bio $(\mathbf{m})$ & L-gli $_{(\mathbf{m})}$ & $\boldsymbol{\Phi}$ & $\boldsymbol{\Phi}_{\mathbf{c}}$ \\
\hline $\mathbf{1 5 , \mathbf { 0 3 . 1 0 } ^ { - 2 }}$ & $1,67.10^{-2}$ & 0,1 & 0,9 \\
$\mathbf{1 3 , 3 6 . 1 0}$ & $3,34.10^{-2}$ & 0,2 & 0,9 \\
$\mathbf{1 1 , 6 9 . 1 0}^{-2}$ & $5,01.10^{-2}$ & 0,3 & 0,9 \\
$\mathbf{1 0 , 0 2 . 1 0}^{-2}$ & $6,68.10^{-2}$ & 0,4 & 0,9
\end{tabular}




\section{$\mathbf{8 , 3 5 . 1 0}^{-2} \quad 8,35.10^{-2} \quad 0,5 \quad 0,9$}

a. L-bio menyatakan ketinggian biodiesel di dalam kolom setelah terjadi separasi secara optimal

b. L-gli menyatakan ketinggian gliserin di dalam kolom setelah terjadi separasi secara optimal

c. $\Phi$ menyatakan fraksi volume fase biodiesel yang terdispersi dalam gliserin, dapat dihitung dengan menggunakan rumus :

$\Phi=\frac{v i(\text { volume total biodiesel })}{V \text { total }(\text { vol bio }+ \text { vol gli })}(19)$

d. $\Phi_{\mathrm{c}}$ menyatakan konsentrasi droplet dalam keadaan rapat, tidak ada ruang gerak satu dengan yang lain (closely packed).

Tabel 4.6. Data harga $\mathrm{k}$ pada tabung diameter $3,9 \mathrm{~cm}$ dan tinggi tabung $16,7 \mathrm{~cm}$

\begin{tabular}{ccc}
\hline $\boldsymbol{\Phi}$ & $\mathbf{\Phi c}$ & $\mathbf{k}$ \\
\hline $\mathbf{0 , 1}$ & 0,9 & 0,192 \\
$\mathbf{0 , 2}$ & 0,9 & 0,384 \\
$\mathbf{0 , 3}$ & 0,9 & 0,577 \\
$\mathbf{0 , 4}$ & 0,9 & 0,769 \\
$\mathbf{0 , 5}$ & 0,9 & 0,961
\end{tabular}

a. Dari grafik 2 di dapat persamaan yaitu :

$y=0,010 \cdot e^{-1,73 x}$

dari rumus diatas di empiriskan terhadap persamaan:

$\mathrm{V}=\operatorname{Vstokes}\left(1-\frac{\Phi}{\Phi c}\right)^{\mathrm{k} . \Phi}$

didapat kesetaraan rumus sebagai berikut :

$\mathrm{e}^{-1,73 \mathrm{x}}=\left(1-\frac{\Phi}{\Phi c}\right)^{\mathrm{k} . \Phi}$

$-1,73 \mathrm{x} \quad \mathrm{k} . \Phi \mathrm{c} ; \mathrm{x} \approx \Phi$

$\mathrm{k}$ b. $\Phi$ menyatakan fraksi volume fase biodiesel yang terdispersi dalam gliserin dalam bentuk satuan.

c. $\Phi_{\mathrm{c}}$ menyatakan fraksi volume fase biodiesel yang terdispersi dalam gliserin dalam satu kesatuan yang rapat yang nilainya sangat dipengaruhi oleh ukurannya, tingkat keberagamannya dan interaksi koloidnya.

d. $\mathrm{k}$ menyatakan suatu konstanta yang nilainya sangat dipengaruhi oleh ukurannya, tingkat keberagamannya dan interaksi koloidnya.

Dalam percobaan dengan diameter kolom tabung $2,8 \mathrm{~cm}$ dan ketinggian kolom $16,7 \mathrm{~cm}$ didapat harga konstanta $\mathrm{k}$ : 0,577 dan harga $\Phi_{c}: 0,9$

\subsection{Waktu pemisahan optimal pada tabung dengan} diameter $3,9 \mathrm{~cm}$ dan tinggi tabung $16,7 \mathrm{~cm}$

Tabel 4.7. Data ketinggian biodiesel dan gliserin setelah pemisahan optimal pada tabung diameter $3,9 \mathrm{~cm}$ dan tinggi tabung $16,7 \mathrm{~cm}$

\begin{tabular}{ccccc}
\hline $\mathbf{t}_{\text {set }}(\mathbf{s})$ & $\mathbf{L}_{\text {-bio }}(\mathbf{m})$ & $\mathbf{L}_{\text {-gli }}(\mathbf{m})$ & $\mathbf{L}(\mathbf{m})$ & $\mathbf{V}_{\text {cream }}(\mathbf{m} / \mathbf{s})$ \\
\hline $\mathbf{8 , 4}$ & $15,03.10^{-2}$ & $1,67.10^{-2}$ & $\begin{array}{c}8,35.10^{-} \\
2\end{array}$ & 0,00994 \\
& & & & \\
$\mathbf{9 , 8}$ & $13,36.10^{-2}$ & $3,34.10^{-2}$ & $\begin{array}{c}8,35.10^{-} \\
2\end{array}$ & 0,00852 \\
& & & & \\
$\mathbf{1 2}$ & $11,69.10^{-2}$ & $5,01.10^{-2}$ & $\begin{array}{c}8,35.10^{-} \\
2\end{array}$ & 0,00714 \\
& & & & \\
$\mathbf{1 4 , 4}$ & $10,02.10^{-2}$ & $6,68.10^{-2}$ & $8,35.10^{-}$ & 0,00580 \\
& & & 2 & \\
& & & & \\
$\mathbf{2 6 , 2}$ & $8,35.10^{-2}$ & $8,35.10^{-2}$ & $8,35.10^{-}$ & 0,00319 \\
& & & 2 &
\end{tabular}

a. $t_{\text {set }}$ adalah waktu dalam detik yang diperlukan oleh biodiesel dan gliserin untuk terpisah secara sempurna / optimal. Pada baris pertama adalah data untuk campuran biodiesel : gliserin dengan perbandingan $9: 1$ dalam kolom setinggi $16,7 \mathrm{~cm}$ dengan diameter kolom 3,9 cm dan seterusnya pada baris kedua dengan perbandingan 8 : 2, baris ketiga $7: 3$, baris keempat $6: 4$ dan baris kelima $5: 5$.

b. L-bio adalah ketinggian biodiesel dalam kolom dan diukur setelah campuran biodiesel-gliserin terpisah secara sempurna.

c. L-gli adalah ketinggian gliserin dalam kolom dan diukur setelah campuran biodiesel -gliserin terpisah secara sempurna

d. L adalah tinggi rata-rata tetesan/droplet dalam kolom, dapat dicari dengan rumus: 
$\mathrm{L}=\frac{1}{2}$ Lbio $+\frac{1}{2} \mathrm{Lgli}$

e. V creaming adalah kecepatan tetesan/droplet melakukan separasi atau terpisah sempurna, dapat dicari dengan menggunakan rumus:

Vcream $=\frac{L}{t \text { set }}$

dimana :

$$
\begin{aligned}
& \mathrm{L}=\text { tinggi rata-rata droplet } \\
& \mathrm{t}_{\mathrm{set}}=\text { waktu separasi }
\end{aligned}
$$

Dari data pada tabel 7 , kemudian diploting antara $\mathrm{t}$ set terhadap V cream, di dapatkan hasil sebagai berikut :

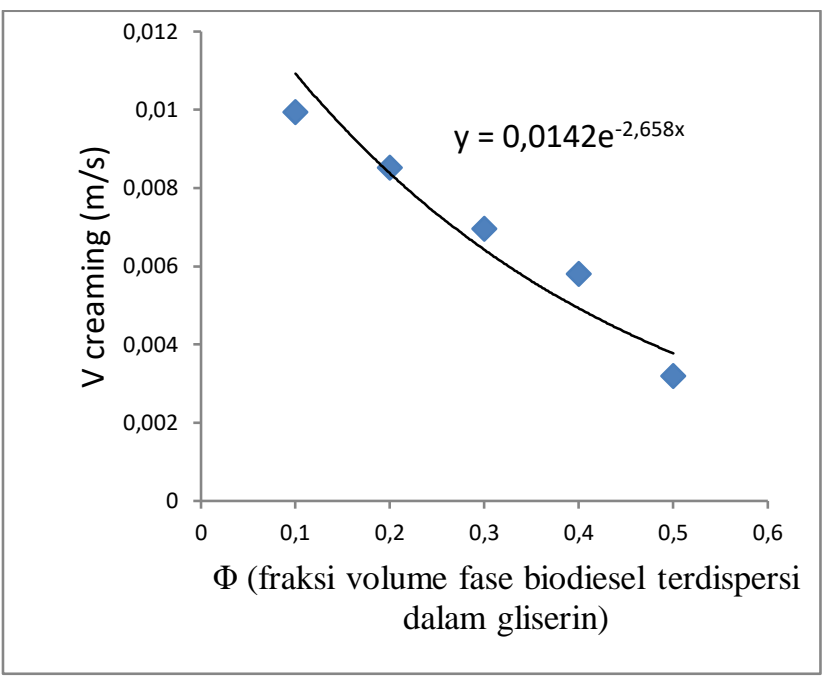

Grafik 3.Grafik t set terhadap V cream pada tabung dengan tinggi $6,9 \mathrm{~cm}$ dan diameter $1,3 \mathrm{~cm}$

a. Sumbu x pada grafik di atas menyatakan waktu separasi optimal dari campuran biodiesel-gliserin dengan perbandingan 9:1, 8:2, 7:3, 6:4, 5:5 atau secara empiris sumbu $\mathrm{x}$ menyatakan jumlah fraksi volume fase biodiesel yang terdispersi dalam gliserin $(\Phi)$

b. Sumbu y pada grafik di atas menyatakan V cream yaitu kecepatan dari tetesan/droplet untuk melakukan separasi secara optimal.

c. Dari rumus V $=$ Vstokes $\left(1-\frac{\Phi}{\Phi c}\right)^{\mathrm{k} . \Phi}$

ketika t set / $\Phi \approx 0$, maka

$\mathrm{V}$ cream $=\mathrm{V}$ stokes $(1-0)$

$\mathrm{V}$ cream $=\mathrm{V}$ stokes
V stokes $=0,014$ dengan nilai

$\mathrm{V}$ stokes $=\frac{d^{2} \cdot g \cdot(\rho g l i-\rho b i o)}{18 \cdot \mu b i o}$ maka

$\mathrm{d} \quad=\sqrt{ } \frac{\text { Vstokes .18. } \mu \text { bio }}{g \cdot(\text { ogli- } \rho \text { bio })}$

sehingga nilai diameter tetesan/ droplet dapat diketahui yaitu nilai diameter tetesan (d) pada tabung dengan diameter 3,9 $\mathrm{cm}$ dan tinggi tabung $16,7 \mathrm{~cm}$ adalah : $5,5 \times 10^{-4} \mathrm{~m}$.

d. Ketika $\mathrm{V}$ cream $\approx 0$

$$
\begin{gathered}
\left(1-\frac{\Phi}{\Phi c}\right) \text { k. } \Phi c=0 \\
\Phi=\Phi c
\end{gathered}
$$

Tabel 4.8. Data $\Phi$ dan $\Phi_{\mathrm{c}}$ dari grafik 3

\begin{tabular}{cccc}
\hline L-bio $_{\text {(m) }}$ & L-gli $_{\text {-m) }}$ & $\boldsymbol{\Phi}$ & $\boldsymbol{\Phi}_{\mathbf{c}}$ \\
\hline $\mathbf{1 5 , 0 3 . 1 0}^{-\mathbf{2}}$ & $1,67.10^{-2}$ & 0,1 & 0,69 \\
$\mathbf{1 3 , 3 6 . 1 0}$ & $3,34.10^{-2}$ & 0,2 & 0,69 \\
$\mathbf{1 1 , 6 9 . 1 0}^{-2}$ & $5,01.10^{-2}$ & 0,3 & 0,69 \\
$\mathbf{1 0 , 0 2 . 1 0}^{-2}$ & $6,68.10^{-2}$ & 0,4 & 0,69 \\
$\mathbf{8 , 3 5 . 1 0}^{-2}$ & $8,35 \cdot 10^{-2}$ & 0,5 & 0,69
\end{tabular}

a. L_bio menyatakan ketinggian biodiesel di dalam kolom setelah terjadi separasi secara optimal

b. L-gli menyatakan ketinggian gliserin di dalam kolom setelah terjadi separasi secara optimal

c. $\Phi$ menyatakan fraksi volume fase biodiesel yang terdispersi dalam gliserin, dapat dihitung dengan menggunakan rumus :

$\Phi=\frac{\text { vi (volume total biodiesel })}{V \text { total }(\text { vol bio }+ \text { vol gli })}(29)$

d. $\Phi_{\mathrm{c}}$ menyatakan konsentrasi droplet dalam keadaan rapat, tidak ada ruang gerak satu dengan yang lain (closely packed).

Tabel 4. 9. Data harga $\mathrm{k}$ pada tabung diameter $3,9 \mathrm{~cm}$ dan tinggi tabung $16,7 \mathrm{~cm}$

\begin{tabular}{ccc}
\hline $\boldsymbol{\Phi}$ & $\boldsymbol{\Phi}_{\mathbf{c}}$ & $\mathbf{k}$ \\
\hline $\mathbf{0 , 1}$ & 0,69 & 0,384
\end{tabular}




$\begin{array}{lll}\mathbf{0 , 2} & 0,69 & 0,768 \\ \mathbf{0 , 3} & 0,69 & 1,152 \\ \mathbf{0 , 4} & 0,69 & 1,536 \\ \mathbf{0 , 5} & 0,69 & 1,920\end{array}$

c. Dari grafik 3 di dapat persamaan yaitu :

$y=0,014 \cdot e^{-2,65 x}$

dari rumus diatas secara empiris terhadap persamaan:

$\mathrm{V}=\mathrm{V}$ stokes $\left(1-\frac{\Phi}{\Phi c}\right)^{\mathrm{k} . \Phi}$

didapat kesetaraan rumus sebagai berikut :

$$
\begin{gathered}
\mathrm{e}^{-2,65 \mathrm{x}}=\left(1-\frac{\Phi}{\Phi c}\right)^{\mathrm{k} . \Phi} \\
-2,65 \mathrm{x}=\mathrm{k} \cdot \Phi \mathrm{c} ; \mathrm{x} \approx \Phi \\
\mathrm{k}=\frac{-2,65 . \Phi}{\Phi c}
\end{gathered}
$$

b. $\Phi$ menyatakan fraksi volume fase biodiesel yang terdispersi dalam gliserin dalam bentuk satuan.

c. $\Phi_{c}$ menyatakan fraksi volume fase biodiesel yang terdispersi dalam gliserin dalam satu kesatuan yang rapat yang nilainya sangat dipengaruhi oleh ukurannya, tingkat keberagamannya dan interaksi koloidnya.

d. k menyatakan suatu konstanta yang nilainya sangat dipengaruhi oleh ukurannya, tingkat keberagamannya dan interaksi koloidnya.

Dalam percobaan dengan diameter kolom tabung $3,9 \mathrm{~cm}$ dan ketinggian kolom 16,7 cm didapat harga konstanta $\mathrm{k}$ : 1,152 dan harga $\Phi_{c}: 0,69$

Tabel 4.10. Data perbandingan nilai $\Phi_{\mathrm{c}}$ dan $\mathrm{k}$ hasil percobaan

\begin{tabular}{ccc}
\hline Percobaan & $\Phi_{\mathrm{c}}$ & $\mathrm{k}$ \\
\hline $\mathbf{1}$ & 0,461 & 5,1 \\
$\mathbf{2}$ & 0,900 & 0,6 \\
$\mathbf{3}$ & 0,690 & 1,2
\end{tabular}

Dari percobaan yang dilakukan diperoleh nilai $\mathrm{k}$ yaitu konstanta yang nilainya sangat dipengaruhi oleh ukuran, tingkat keberagaman serta interaksi koloid dalam larutan dan nilai $\Phi_{c}$ yaitu fraksi volume fase biodiesel yang terdispersi rapat dalam gliserin yang nilainya juga sangat dipengaruhi oleh ukuran, tingkat keberagaman serta interaksi koloidnya di dapatkan angka yang berbeda dari peneliti sebelumnya yaitu pada peneliti sebelumnya nilai $\mathrm{k}$ dan $\Phi_{\mathrm{c}}$ masing- masing adalah : 5,4 dan 0,585 sedangkan pada percobaan yang dilakukan didapatkan nilai $\mathrm{k}$ dan $\Phi_{\mathrm{c}}$ masing - masing adalah $(5,1 ; 0,6 ; 1,2)$ dan $(0,461 ; 0,9$; $0,69)$ pada percobaan I, II, III dengan diameter $(1,3 ; 2,8$; $3,9) \mathrm{cm}$.

\section{Kesimpulan}

1. Hasil pengukuran pada ketiga kolom tabung percobaan dapat disimpulkan bahwa semakin besar nilai konsentrasi tetesan/droplet $(\Phi)$, maka nilai kecepatan pemisahan / Vcream semakin berkurang.

2. Dari percobaan yang dilakukan di dapatkan nilai $\mathrm{k}$ dan $\Phi_{c}$, masing - masing adalah $(5,1 ; 0,6 ; 1,2)$ dan $(0,461$; $0,9 ; 0,69)$ pada percobaan I, II, III dengan diameter $(1,3$ ; 2,$8 ; 3,9) \mathrm{cm}$.

\section{Daftar Pustaka}

Cengel, Y.A., \& Boles, M.A.(2002).Thermodynamics : An engineering approach. New York, NY: NcGrawHill.

Das. P. (1997). Prediction of settling velocity of drops in a concentrated batch liquid-liquid dipersion. Chemical Engineering and Technology, 20,475-477.

Holman, J. P. (2001). Experimental methods for engineer. New York. NY: McGraw-Hill.

Nadiv, C. \& Semiat, R. (1995). Batch settling of liquidliquid disperion. Industrial and Engineering Chemistry Research, 34,2427-2435.

Perry, R.H., \& Green, D.W. (1997). Perry's chemical engineer's handbook. New York, NY:McGraw-Hill.

White, F.M. (2003). Fluid mechanics. New York. NY:McGraw-Hill. 